\title{
Administrative Measures Problems in Medan Mayor Regulation Number 11 of 2020 Concerning Health Quarantine in the Accelerated Handling of Covid-19
}

\author{
Eka N.A.M. Sihombing ${ }^{1, *}$, Cynthia Hadita ${ }^{2}$ \\ ${ }^{1}$ Faculty of Law, Universitas Muhammadiyah Sumatera Utara, Indonesia, \\ ${ }^{2}$ Master Program in Law, Universitas Sumatera Utara, Medan, Indonesia \\ *Corresponding author: ekahombing@umsu.ac.id
}

\begin{abstract}
Medan Mayor Regulation Number 11 of 2020 concerning Health Quarantine in the Context of Accelerating Handling of Corona Virus Disease 2019 (COVID-19) in Medan City, hereinafter referred to as Regulation of Mayor (Perwal) COVID. Based on the COVID-19 regulation, the Medan city government began to carry out mask raids in various crowded places, to several violators. The Civil Service Police Unit personnel immediately took administrative actions, one of which was the detention of electronic identity card (KTP-el). The purpose of this research is to unravel the problem whether the administrative measures contained in the COVID-19 regulation are in accordance with the general principles of good governance and higher legislation. The method used in this paper is normative juridical legal research, using an approach to legal principles and statutory regulations. The nature of the research used in this paper is prescriptive. The results showed that administrative action in the form of detention of KTP-el is formulated inaccurately. Such actions have the potential to cause members of the public to violate the provisions of other laws and regulations which result in the imposition of administrative fines based on the provisions of Article 63 (5) jo. Article 91 (1) of Law No. 23 of 2006 concerning Population Administration as amended by Law No. 24 of 2013.
\end{abstract}

Keywords: administrative action, mayor regulation, COVID-19.

\section{INTRODUCTION}

In the scope of administrative law, to ensure compliance against a rule, the government is given the authority to load the sanctions in the form of coercion of government (bestuurdwang). Having the free authority (vrije bevoegheid), the government is given freedom to consider its initiative to use the coercion of government or not or even apply other sanctions, but in terms of the use of coercion the government, it is bound by the General Principles of Good Governance.

In this regard, the Government of the City of Medan on April 30, 2020 promulgate Medan Mayor Regulation Number 112020 about the Quarantine of Health to accelerate the Handling of Corona Virus Disease in 2019 (COVID19), hereinafter referred Perwal COVID. Based on this regulation, the Medan city Government began to conduct masks searches at various crowded places.
To some offenders, the personnel of the Civil Service Police Unit directly performs certain administrative actions, one of which is in the form of electronic ID card detention.

The policy will also give implications for the government of Medan city that does not have the legitimacy to implement that rule. Therefore, that can contain sanctions to ensure the Laws and Regulations of the Area. If the rule was made in the form of Medan mayor regulation. Moreover, contrary to some laws and regulations and in the name of human rights. It will injure the joints of the existing law.

Human rights in Indonesia originate from and lead to Pancasila, which means that human rights have a strong guarantee from the nation's Pancasila philosophy. Leading to Pancasila, it means that the implementation of human rights must pay attention to the lines that have been determined in the 
provisions of the Pancasila philosophy. For the Indonesian people, exercising human rights does not mean exercising freely, but must pay attention to the provisions contained in the Indonesian people's view of life, namely Pancasila. This is because there are no rights that can be exercised in multiple ways without considering the rights of others. Each right will be limited by the rights of others. Failure to pay attention to the rights of others in exercising our rights wil result in a conflict of rights or interests in the life of the community, nation, and state.[1]

The regulation is set in Article 63 (5) jo. Article 91 (1) of Law No. 23 Year 2006 about Population Administration as amended by ACT No. 24 of 2013 (the ACT Adminduk), stating that each population has an obligation to adhere to, and any violation to the provision is subject to an administrative fine. However, the existence of Perwal COVID will make people lose their rights and impeded in performing its obligations to carry ID cards-el.

The division of power vertically in a unitary state brings consequences for the presence of a central government domain and a local government environment.[2] There will be other logical consequences, namely the existence of a relationship between the center and the regions to avoid overlapping the implementation of authority. In addition, the result of adopting a regional autonomy system is related to the relationship of authority between the center and the regions.[2] Among other things, the authority relationship is related to determining regional household affairs. In implementing regional autonomy and coadministration based on Article 18 Paragraph (6) of the 1945 Constitution of the Republic of Indonesia, regional governments have the right to form regional regulations and other regulations. One of the instruments of "other regulations" referred to in the provision is the Regional Head Regulation. Regional Head Regulations are regional legal products whose content is to implement local regulations or are authorized by statutory regulations. The Regional Head Regulation, contains the formulation of administrative and governmental actions, but in the formulation it is certainly bound by the principles of the formation of good laws and regulations, the principles of the material content of statutory regulations, and the principles of good general governance.

In this regard, in the context of accelerating the handling of COVID19, the Medan City Government, on April 30, 2020, enacted Medan
Mayor Regulation Number 11 of 2020 concerning Health Quarantine in the Context of Accelerating Handling of Corona Virus Disease 2019 (COVID19) in Medan City hereinafter referred to as Perwal COVID. In the COVID-19 Regulation, the Medan city government formulates administrative measures for violators of the Perwal in the form of electronic ID cards detention.

This paper attempts to parse the Formulation of Administrative Measures in the COVID19 Regulation whether it is following the Principles of the Formation of Laws and Regulations, the Principles of Material Content of Legislation, and the Principles of General Good Governance.

\section{RESEARCH METHOD}

The method used in this paper is normative juridical legal research, by using the approach to the Principles of law and legislation. The nature of research used in this paper is prescriptive.

Soerjono Soekanto explained that normative legal research is usually carried out by examining literature and secondary data which includes research on legal principles, legal systematics, levels of legal synchronization, legal history, and comparative law.[3] Meanwhile, Peter Mahmud Marzuki said the research approach model in legal research includes the statute approach, the case approach, the historical approach, the comparative approach, and the conceptual approach.[4]

The purpose of this research is to unravel the problems, whether administrative action contained in Perwal COVID is consistent with the principles of the general principles of good government. The author will elaborate between the mayor's regulations and government's data in the field proving that as of November 26, 2020, the suspected covid-19 has become 281 people. Among 7,566 confirmed cases, 6197 people are recovered and as many as 315 people died. For those who are not familiar with Covid-19, the legal regulations in the regions need to make people obey the rules but by not confiscating identity cards which also cause people to have something other unfamiliar because they don't bring their KTP-el.

\subsection{Approach}

The method used in this research is normative juridical legal research method.[5] A normative research must use a statutory approach (statute approach) because the objects of the study are various legal rules. Taking Dworkin's term, this 
kind of research is also called doctrinal research, a type of research that analyzes law, both written in a book (law as it is written in the book). In this research, literature and document studies are used as the main material.

\subsection{Data Collection Methods}

The technique of collecting legal materials used in this research is library research by conducting document studies in private libraries and law libraries at the Regional Office of the Ministry of Law and Human Rights of North Sumatra.

\subsection{Data Analysis Techniques}

Data analysis is the process of organizing and sorting data into categories and basic description units, so that themes are found and work hypotheses can be formulated, as suggested by the data. Data (legal materials) that have been obtained from library research are analyzed using Data Analysis Techniques.

\section{FINDINGS AND DISCUSSION}

Several problems have been found in the formation of the COVID-19 Regulation, the first of which is related to the passing of regional regulations, because this mayor regulation was made without degradation from the existing regulations above. In addition, the legal substance that it regulates is contrary to the rules and rights held by the community. In connection with the hierarchy of mayor's regulations, as well as various conflicting principles that do not adhere with the formation of these rules will be discussed in the discussion of the existence of mayor's regulations, the process of forming mayor regulations related to Covid, and also regarding regional autonomy and community protection that should be carried out by local governments. However, the juridical regulations and facts show inconsistent conditions.

\subsection{Regional Autonomy and Community Protection}

Regulatory contestation in the face of Covid-19 has legal dynamics. Then, covid-19 was designated as a non-natural disaster through Presidential Decree No.12 of 2020 concerning the Determination of Non-Natural Disaster for the Spread of Corona Virus Disease 2019 (COVID-19) as a National Disaster. In addition, the existence of precarious urgency has resulted in existing Government Regulation in Lieu of Law Number 1
Year 2020 regarding State Financial Policy and Financial System Stability for Handling Pandemic Corona Virus Disease 2019 (COVID-19) and / or in the Context of Facing Threats that Endanger the National Economy and / or System Stability.

According to the Encyclopedia of Social Science, the definition of autonomy is the legal self-sufficiency of social body and its actual independence. Thus, the notion of autonomy involves two main matters, namely: the authority to make own laws and the freedom to regulate selfgovernment). Based on this definition, regional autonomy is essentially the right or authority to manage one's own household for an autonomous region.[6]

Autonomy in the context of hierarchical relations associated with the distribution of power vertically is defined as the surrender to or allowing each lower government to fully regulate and manage certain governmental affairs, both regarding the principles and how to run them.[7]

Basically, there are three main reasons why regional autonomy is needed. The first reason is to do with political equality, which is to increase community political participation at the local level. The second is local accountability, which is increasing the capacity and responsibility of local governments in realizing the rights and aspirations of local communities. The third is local responsiveness, namely increasing the response of local governments to socio-economic problems that occur in their regions.[8]

The government has the power to regulate public interest holdings through legislation, or the application of legal sanctions. General principles of good governance that uphold standards of decency, and the rule of law must be applied when making laws.[9] Administrative law is a special rule of law established based on the competence of the state.[10] Indonesia to recognize the existence of government discretion (freies emerssen). But it must nevertheless be based on the principle of the formation of better laws and regulations.[11]

The state government cannot act arbitrarily to carry out the actions. State law has the principle that any action by the public administration must always be based on applicable law and has been there before the action was taken. This principle is known as the legality principle.[12]

Law No. 23 of 2014 guarantees the principles and principles of regional autonomy. The Unitary State of the Republic of Indonesia is divided into 
Provinces, Regencies, and Cities. The relevant regional government authorities regulate and manage government affairs according to decentralized, deconcentrated, and co-administered tasks. The division of these areas should make it easier for the community to empower the community participation function.

The widest possible autonomy does not mean without limits and does not refer to various regulations above it. Furthermore, regional heads in enacting regulations cannot be carried out without looking at the existing regulations above them, because the hierarchical indiscipline, and also the placement of substances that are not in the type of regulation will have an impact on the inability of local governments. In addition, the civil service police unit (SATPOL PP) as the implementer of regional regulations and regional head regulations must have accountability in carrying out their duties while still having to protect the community by not detaining KTP-el and even imposing push-ups on people who do not wear masks. Regarding the responsibility of SATPOL PP, it is regulated in Article 1 number 1 of Government Regulation Number 16 of 2018 concerning Civil Service Police Units that "Civil Service Police Unit, hereinafter referred to as Satpol PP, is a regional apparatus established to enforce Regional Regulations and Regional Head Regulations, carry out public order. and tranquility and protect the community.

Principles that need to serve as guidelines for making the substance of statutory regulations must be based on the principle of clarity of objectives, principles of appropriate institutional or forming organs, principles of conformity between types and content of content, principles of enforceability, principles of utility and efficiency, principles of clarity of formulation, principles openness. The principle of content material refers to Law Number 12 of 2011 that the laws and regulations must be based on these principles: the principle of protection, the principle of humanity, the principle of nationality, the principle of kinship, the principle of nationality, the principle of unity in diversity, the principle of justice, the principle of equality in law and governance, the principle of order and legal certainty, the principle of balance, harmony and harmony;

Conducting a juridical analysis related to regional autonomy and community protection of the existence of regulations to accelerate the handling of Covid, but in the form of a mayor's regulation that contains administrative sanctions, we can see the authority and legitimacy of local governments through the relevant articles regulated in Article 246 of Law 23 of 2014 paragraph:

(1) To implement a regional regulation or at the power of statutory regulations, the regional head shall stipulate a Perkada.

(2) The provisions regarding the principles of formation and content, as well as the formation of the Regional Regulation as referred to in Article 237 shall apply mutatis mutandis to the principles of formation and content, as well as the formation of the Regional Heads.

In reality, Medan Mayor Regulation No. $11 / 2020$ concerning Health Quarantine in the Context of Accelerating Handling of Corona Virus Disease 2019 (COVID19) in Medan City was made without the power of local regulations or statutory regulations. So, the local government violates this rule.

The application of the principle in a perda is the same as the principle in the formation of regional regulation. This is regulated in Article 237 paragraph (1) of Law 23 of 2014 which regulates that "The principles for the formation and content of Perda are guided by the provisions of statutory regulations and legal principles that grow and develop in society as long as they are not in conflict with the principles of the Unitary State of the Republic. Indonesia". Article 237 paragraph (3) of Law 23/2014 "The public has the right to provide input orally and / or in writing in the formation of Perda". Article 237 paragraph (4) of Law 23/2014 "The formation of the Regional Regulation as referred to in paragraph (2) is carried out effectively and efficiently".

The imbalance in the COVID-19 situation is caused by the failure to adhere to several principles such as the principle of clarity of objectives, the principle of proper institutional or forming organs, the principle of conformity between types and material of content, the principle of being able to be implemented, the principle of clarity of formulation, the principle of openness. Their effectiveness and efficiency are also not guaranteed because, despite this regulation, there are still many people who do not wear masks during the COVID19 pandemic. In addition, Article 237 paragraph (3) of Law 23/2014, regarding verbal / written input, is not empowered, because the existence of the regulation causes a controversial and social upheaval that appears as an implication for the existence of the regulation. In more detail, referring to the humanitarian principle, detaining KTP-el, applying push-up penalties to Medan city people who do not use masks by using regulations only in 
the form of COVID regulations without any rules on it and which should not be in the form of a perda but in that perda, contrary to human rights.

Citizens are obliged to carry their own identity in the form of KTP-el when getting around, otherwise, they will be subject to administrative sanctions, this is as regulated in Article 63 paragraph (5) of Law No. 23 of 2006 concerning Population Administration as amended by Law No. 24 of 2013 (UU Adminduk), stipulates that "Residents who already have a KTP-el are required to bring them ". Article 91 paragraph (1) of the Adminduk Law "Every resident as referred to in Article 63 paragraph (5) who travels without carrying an ID card is subject to an administrative den of a maximum of Rp. 50,000.00 (fifty rupiah)". If the Medan city government through SATPOL PP detains KTP-el against people who do not wear masks, it will limit the rights of residents in carrying out their obligations in terms of carrying KTP-el.

\subsection{Content of Regional Head Regulations}

Emilie Hafner-Burton et al. defined derogation as "a rational response to [The] uncertainty, enabling governments to purchase the time-space and legal breathing space of voters, courts, and interest groups to combat the temporary crisis by civil and political freedoms". Derogation clauses do not, according to Gerald L. Neuman, contradict the idea of true humans but may on the contrary contribute to their effective protection. Indeed, states have a positive obligation to protect the right to life, which may justify insulting some other human rights. In Indonesia, there are two procedural steps use to investigate the validity of a legal product and its conformity with the constitution.[13]

Several problems have been revealed in the formation of the COVID-19 Regulation. The first problem is related to the passing of regional regulations because this mayor's regulation was made without degradation from the existing regulations above. In addition, the legal substance that it regulates is contrary to the rules and rights held by the community. In connection with the hierarchy of mayor's regulations, as well as various conflicting principles that are not adhered to in the formation of these rules will be discussed in the discussion of the existence of mayor regulations, the process of forming mayor regulations related to Covid, and also regarding regional autonomy and community protection that should be carried out by local governments. The juridical regulations and facts, however, show inconsistencies.

The systematic chronology of statutory regulations in Indonesia is regulated in Article 7 of Law Number 12 of 2011 concerning the Formation of Legislation Types and hierarchy of statutory regulations consisting of:

1. The 1945 Constitution of the Republic of Indonesia;

2. The Decree of the People's Consultative Assembly;

3. Laws / Government Regulations in Lieu of Laws;

4. Government Regulations;

5. Presidential Regulation;

6. Provincial Regulations; and

7. Regency / City Regulations

Article 1 No. 8 in Law No. 15 of 2019 concerning Amendments to Law Number 12 of 2011 concerning the Establishment of Legislation that the Definition of Regency / City Regional Regulations is Legislations established by the Regional Representative Council of City regencies with the joint approval of the Regent / Mayor.

Furthermore, in Law Number 12 of 2011 concerning the Formation of Legislative Regulations in Article 15 paragraph (1) The contents of the criminal provisions can only be contained in:

1. Law;

2. Provincial Regulations; or

3. District / City Regional Regulations.

Article 15 paragraph (2) "The criminal provisions as referred to in paragraph (1) letters $b$ and $\mathrm{c}$ are in the form of a maximum imprisonment of 6 (six) months or a maximum fine of Rp.50,000,000.00 (fifty million rupiah)". Article 15 paragraph (3) "it is stipulated that the Provincial Regulations and Regency / City Regulations can contain the threat of imprisonment or fines other than those referred to in paragraph (2) in accordance with what is regulated in other Legislation".

That way, imprisonment and fines can only be applied by laws, provincial regulations and regency / city regulations. Mayor's Regulation is not authorized for that. In this case, the detention of KTP-el which is regulated in the form of a mayor's regulation is contrary to the law regarding the formation of that statutory regulation.

The form of similar legal instruments or legal instruments that are lower than the relevant laws and regulations. Orders to form further provisions 
in statutory sciences are called Delegation of authority. This delegation of authority is generally given to the initiator to make further legal arrangements so that the provisions stipulated in the relevant law can be implemented properly. The order for the establishment of further regulations to State / Government Institutions is the delegation of authority to the formulation of Legislation is the handover or delegation of responsibility to others for the right and power to act and the granting of authority to other parties to establish legislative instruments. In other words, the delegation of authority for the formation of laws and regulations is the delegation or provision of a portion of authority to institutions/agencies, government ministries / non-ministries, provincial governments, and municipal governments in the framework of establishing a legal instrument to implement a statutory regulation.[14]

Article 8 paragraph (1) of Law 12/2011, stipulates that: Types of Legislation other than those referred to in Article 7 paragraph (1) include regulations stipulated by the People's Consultative Assembly, the House of Representatives, the Regional Representative Council, the Supreme Court, the Constitutional Court, the Supreme Audit Agency, the Judicial Commission, Bank Indonesia, the Minister, agencies, institutions, or commissions that are at the same level as established by law or the government at the behest of the law, the Provincial People's Representative Council, the Governor, the Regency / City Regional People's Representative Council, the Regent / Mayor, the Village Head or equivalent.

Article 42 paragraph (1) Permendagri No. 120 of 2018 states "The regional head determines a regional head based on the order of a higher level of legislation or is formed based on authority". Article 42 paragraph (2) Permendagri No. 120 of 2018 contain "The leader of the initiating regional apparatus prepares a draft district head". Article 42 paragraph (3) Permendagri No. 120/2018 contain "The draft district head, after being drafted, is submitted to the provincial legal bureau or other names and district/city legal departments or other names for discussion".

Hart's thoughts lead to laws made based on the existence of an authorized authority to regulate people's lives. Legal authority lies because of the commands and sanctions that have causality.[15]

Referring to the hierarchy discussed in the previous subsection, it is not clear that the existence of a mayor regulation explicitly in Article 7, however, further Article 8 Regents / Mayors are included in the types of legislation. In essence, the Mayor Regulation has a significant difference in the process of making regulations from the process of making a regional regulation. This is because mayoral regulations are only made by local governments (mayors) while regional regulations are made by local governments (mayor + DPRD). An indication of mayor's regulations that are not as aspirational as regional regulations because they do not absorb the people's aspirations in the making process because the discussion is only carried out by the city government internally. Moreover, the process of making rules relating to public administration, in this case the KTP-el, should involve the population and civil registration offices to review them from a legal perspective so that the rules made are not contradictory.

More importantly, the Medan mayor regulation is made not a degradation of the regional regulation but bypassing the existence of a regional regulation. Apart from the process of that Medan mayor regulation, and the regulated content of the law is inconsistent, between hierarchies is also conflicting, including not reflecting a good type of legislation.

It shows from the provisions of Article 25 paragraph (2) letter b of the Covid Perwal which authorizes the Covid Task Force to carry out administrative actions for citizens, legal entities, or officials, which are contrary to the provisions of the Covid Regulation in the form of: verbal warning, warning notification, detention ID, restriction / termination / activity dissolution, temporary closure, license suspension, and license revocation.

The discriminatory provisions are because they are influenced by administrative actions that only affect community members, devices, or entities, while entities that are not included as companies within the scope of the Civil Code, CVs, companies, etc. are not included in the provisions of the Covid Perwal, so they are considered not fulfilling the principle of impartiality, where this principle requires the government not to discriminate against officials in making decisions or actions.

Judging from the material contained in the COVID-19 Regulation, in principle it has been comprehensively regulated in Law 6/2018 on Health Quarantine (Quarantine Law) along with criminal sanctions for everyone who does not comply with the implementation of Health Quarantine. Even, this criminal sanction is not only contained in the Quarantine Law. However, there 
are also provisions in Law 4/1984 concerning Outbreaks of Communicable Diseases, Articles 214, 216 (1), 218 of the Criminal Code. Apart from that, from the various laws and regulations that were used as the legal basis for the Covid Regulation, no delegation ordered further regulation to the Perwal. The Quarantine Lawt contains a mandate for local governments to be involved in home quarantine, regional quarantine, and hospital quarantine. The local government is also responsible for fulfilling the basic living needs of those affected by the quarantine. The Permendagri Number 20/2020 contains an arrangement that mandates the Regional Government to form a COVID Task Force Team and manage funds in handling COVID. In addition, the COVID-19 Regulation is also not a regulation to implement the Regional Regulation, because indeed the Regional Regulation that regulates health quarantine and handling of COVID in Medan City has not yet been determined.

\subsection{Administrative Action in Perwal COVID}

International human rights law guarantees the right of all people at the highest level of Health and requires governments to take steps to prevent threats to public health and provide medical care to those who need it.[16] Nomoi as one of Plato's books states that good governance of the country is based on the institution of good law, Aristotle further adds that a good rule of thumb, if it is governed by the constitution and various degradation. Shahran Law pointed out that civil protection is given when the administrative action affects the loss. The legal protection of the citizens is a universal concept adopted and diversified by different countries.

Government action is every action of a state administrative tool (bestuurorgan) covering actions or matters outside the field of state administrative law, such as security, and others. The essence of administrative action has benchmarks and standardization in relation to whether a government institution is authorized to exercise its authority to contain the substance of administrative actions that will be applied to the public through the regulations made. The right to exercise authority is inseparable from the existence of the government in state administrative law as an authorized body. Thus, the government often makes decisions with the same authority, namely "state authority" or "public authority".
Van Vollen Hoven argues that governmental action (bestuurshandelingen) is an act in the framework of maintaining the interests of the state and the people spontaneously and independently by high or low authorities. The Van Poelje Commission, based on its report in 1972, defines publiek rechtelijkehandeling (actions in public law) as legal actions taken by the authorities in carrying out government functions.[17]

In the scope of state administrative law, to ensure public compliance with a regulation, the government is given an authority to impose sanctions in the form of government coercion (bestuurdwang). The authority of the government to use government coercion is a free authority (vrije bevoegheid), in the sense that the government is given the freedom to consider on its initiative to use government coercion or not or even apply other sanctions, but in terms of using government coercion, the government is bound by the Principles- Good General Principles of Governance (see Ridwan HR, 2011: 307). Such as the principle of legal certainty, the principle of expediency, the principle of impartiality, the principle of accuracy, the principle of openness, and so on.

Regarding the material of administrative sanctions (as government coercion) contained in the Perwal, it is also reasonable to suspect that it contradicts several general principles of good governance. First, with regard to the formulation of the provisions of Article 25 (2) letter $b$ of the COVID-19 Regulation which authorizes the COVID Task Force to carry out Administrative Actions to members of the public, officials, or legal entities that violate the provisions of the COVID-19 Regulation in the form of: verbal warning, warning, detention of identity cards, limitation/cessation/dissolution of activities, temporary closure, license suspension, and license revocation. This provision should be suspected of being discriminatory because those affected by the administrative action are only members of the public, officials, or legal entities, meanwhile for entities that are not legal entities such as civil associations, CVs, firms, and so on are not included in the provisions of the COVID-19 regulation. Therefore, it is considered not fulfilling the principle of impartiality, where this principle obliges government officials to make decisions or acts not to be discriminatory.

Second, with regard to administrative measures in the form of detention of KTP-el, it should be suspected that they were formulated inaccurately. Such actions have the potential to cause members 
of the public to violate the provisions of other laws and regulations which result in the imposition of administrative fines. Based on the provisions of Article 63 (5) jo. Article 91 (1) of Law No. 23 of 2006 concerning Population Administration as amended by Law No. 24 of 2013 (Adminduk Law) states that every resident must carry it when traveling. If this provision is violated then will be subject to administrative fines. In addition, the detention of these KTP-el also has the potential to cause members of the community to lose other rights that require the use of identity cards in the form of KTP-el. So it is reasonable to suspect that this provision contradicts the principle of accuracy which requires that every decision or action be based on complete information and documents (in this case juridical documents) to support the legality of a decision or action before it is stipulated.

\section{CONCLUSION}

Based on the description above, it can be concluded that the material for the content of the COVID-19 regulation in the city of Medan, especially those related to administrative actions, is not following the principle of the formation of laws and regulations, especially the principle of proper content, because in addition to not being delegated by regional regulations or higher legislation, the material the contents have also been regulated in such a way by various provisions of higher laws and regulations. Regulations regarding health quarantine in the higher statutory regulations can be implemented in principle without the presence of the COVID-19 pandemic. In fact, the presence of this COVID-19 regulation creates legal uncertainty because an act of non-compliance with the implementation of health quarantine can be subject to different sanctions by several laws and regulations. In addition, the sanctions contained in the COVID-19 regulation, especially those related to the detention of KTP-el, even though they have been formally enforced, have no validity because that's contradictive with the higher legislation, especially the Adminduk Law.

We also understand that the stipulation of the COVID-19 Regulation is the good intention of the Medan City Government which seeks to reduce the rate and break the chain of the spread of the COVID19 virus, but don't let this good intention tarnished by establishing a regulation that ignores various parameters that have been determined by the general principles of governance good principles as well as the principles of forming laws and regulations.

\section{AUTHORS' CONTRIBUTIONS}

Author's contributions are to collect the data, journals, books, the fundament of law, give opinion each other. After that, author's make this research paper.

\section{ACKNOWLEDGMENTS}

Special thanks we are delivered to Faculty of Law, Universitas Muhammadiyah Sumatera Utara for always support us to be productive research.

\section{REFERENCES}

[1] E. N. A. M. Sihombing, "Pemberlakuan 'Parliamentary Threshold' dan Kaitannya dengan Hak Asasi Manusia," J. Konstitusi, vol. 1, no. 1, p. 28, 2019.

[2] E. M. J. Ali Marwan HSB, "Pelaksanaan Kewenangan Atribusi Pemerintahan Daerah Berdasarkan Undang-Undang Nomor 23 Tahun 2014 Tentang Pemerintahan Daerah," J. Legis., vol. 15, no. 2, p. 3, 2018.

[3] S. Soekanto, Pengantar Penelitian Hukum. Jakarta: UI Press, 2012.

[4] Audrey, "COVID-19 pandemic and derogation to human rights Lebret," Oxford Univ. Pres, J. Law Biosci., vol. 7, no. 1, 2020.

[5] J. E. and J. Ibrahim, Metode Penelitian Hukum (Normatif Dan Empiris). Jakarta: PrenadaMedia, 2018.

[6] Sjafrizal, Perencanaan Pembangunan Daerah dalam Era Otonomi. Jakarta: Rajawali Pers, 2015.

[7] P. M. Hadjon, Pengantar Hukum Administrasi Indonesia; Introduction to Indonesian Administrative Law. Yogyakarta: Gadjah Mada University Press, 2002.

[8] E. N. A. M. S. dan Irwansyah, Hukum Tata Negara. Medan: Enam Media, 2019.

[9] D. Syahrizal, Hukum Administrasi Negara \& Pengadilan Tata Usaha Negara. Yogyakarta: Pustaka Yustisia, 2012.

[10] R. HR, Hukum Administrasi Negara. Yogyakarta: UII Press Indonesia, 2002. 
[11] W. D. . Voll, Dasar-Dasar Ilmu Hukum Administrasi Negara. Jakarta: Sinar Grafika, 2013.

[12] D. H. Koentjoro, Hukum Administrasi Negara. Bogor: Ghalia Indonesia, 2004.

[13] R. M. Sukmariningsih, "Some Key Issues in the Cancellation of Local Regulations in Indonesia," J. Leg. Ethical Regul., vol. 22, no. $1,2019$.

[14] Zaelani, "Pelimpahan Kewenangan Dalam Pembentukan Peraturan PerundangUndangan," J. Legis., vol. 9, no. 1, 2012.

[15] Cynthia Hadita, "Registrasi Data Pribadi Melalui Kartu Prabayar Dalam Perspektif Hak Asasi Manusia (Provision of Personal Information in Prepaid SIM Card Registration from Human Rights Perspective)," J. HAM, vol. 2, no. Desember 2018, 9AD.

[16] Joseph J. Amon, "Wurth, A Virtual Roundtable on COVID-19 and Human Rights," Heal. Hum. Right J.

[17] T. Sudrajat, Perlindungan Hukum Terhadap Tindakan Pemerintahan. Jakarta: Sinar Grafika, 2020. 